\title{
Relativizált nemi micsodák
}

\author{
HORVÁTH JÚLIA BORBÁLA ${ }^{1}$
}

\begin{abstract}
ABSZTRAKT
A társadalmi nemek megfogalmazásának sokat vitatott iránya a gender-elmélet, s annak azon elképzelése, hogy a biológiai nem másodlagos, és az attól eltérés szabadon választható. A kapcsolódó társadalmi konstrukció, a transzgender vagy transznemúség fogalma, az 1990-es években kialakult a poszt-strukturalista filozófia szülöttje volt. Napjainkban a témában számos elmélet keveredik, s úgy tûnik, hogy egy viszonylag szük létszámú kisebbség igyekszik befolyásolni a többség irányultságát. E cikk a gender-elméletek radikális irányzataira tér ki, azokra, amelyek oly módon próbálkoznak az egyén identitásának megváltoztatással, hogy a született, biológiai nemet relativizálják, vagy szembeállítják a társadalmi nemmel. Ez esetben nem a biológiailag transz-nemúekrôl (transzszexuális, interszexuális stb.) lesz szó, hanem a választott, vagyis a társadalmi nemi értelemben vett szerepek, és ahhoz kapcsolódó ideológiák taglalásáról, amely mellett megemlítódik egy praktikus alternatíva, a köztes vagy intermentalitás fogalmának vázlata.
\end{abstract}

KULCSSZAVAK: társadalmi nemi szerepek; gender-teóriák; mentalitásváltozás; köztes mentalitás, intermentalitás; a nők története; a biológiai és a társadalmi nem

\section{ABSTRACTS}

\section{Relativized gendergizmos}

Gender-theory is an arguable direction of social gender phrasing; especially its concept, that deviancies from the biological orientation are optional. The notion of transgender ortrans-sexuality as a social construction evolved in the 1990's from post-structuralist philosophies. Nowadays multiple theories are mingled, and a relatively small minority seems to determine the majority's traditional orientation. Present article is to discuss radical wings of gender theories, especially the ones that aim to alter the individual's identity by relativizing the natural born biological sex, or by opposing it with social gender. Instead of dealing with the biological trans-gender (trans-sexuality, intersexuality, etc...), present work researches chosen gender, or the social gender roles and the corresponding ideologies; as well as a practical alternative, the intermentality outline topic.

KEYWORDS: gender-theories; mentalitychange; intermentality, the history of women, biological and social gender

\footnotetext{
${ }^{1} \mathrm{PhD}$, kulturális antropológus.
} 


\section{KÖZELKÉP}

\section{Bevezető}

A XX. század második felében elterjedt funkcionalista megközelítés - a nő első sorban anya, és részére a munkamegosztás javarészt a reprodukciót szolgálandó feladatokat jelenti -, nemkívánatossá vált. Addig a férfi és a nő közötti nemi különbséget a sex szóval jelölték, amely szintén változott, és megszületett a gender fogalma. A gender-elmélet eredetileg a tipizált férfi- és női szerepek tetszés vagy szükség szerinti gyakorlását jelentette. A Robert Stoller pszichoanalitikus által bevezetett alap-meghatározás ontológiai alapokon nyugszik (Huszár 2009: 20). Fő gondolata, hogy a nemek közötti eltérést nem döntően a testi- biológiai különbség, hanem a mindenkori társadalom által konstituált férfi és női nemi szerepkörök határozzák meg. A megértésben és a megértetésben több definíció is született.

Félreértések már a kezdetkor kialakultak (1970-80-as évek), például az angol gender kifejezés lefordíthatatlansága miatt. A latin nyelvekben, a megegyező kifejezések (francia: le genre, spanyol: el genero) eredetileg nem jelölnek biológiai hovatartozást (bár a névelő: 'le' hímnemet jelez), ezért a sex és a gender jelentése minduntalan összekeveredett. A másik gondot a biológiai sex/sexus és a társadalmi gender szétválasztásának megértetése okozta. A kortárs Scott úgy vélte, hogy a 'gender' nemcsak a biológiai test kulturális tartalommal értelmezett kategóriája. E véleményével azon feministák közé tartozott, akik nem értettek egyet a szexuális különbség és a társadalmi nem (gender) azonosságával. ${ }^{2}$

A gender fogalmát, az 1990-es évektől napjainkig minduntalan újrafogalmazták. Lacan a társadalmi nemi szerepek területéről mint a biológia és a kultúra konvergálásáról, de nem okozati összefüggéséről beszélt (Lacan 1977). Mason definíciója: „gender rendszer alatt a női és férfiviselkedésre vonatkozó társadalmilag konstruált elvárásokat értjük, melyek változatos formában ugyan, de minden ismert emberi társadalomban megtalálhatóak." (Mason 1997: 158). Eszerint, a gender rendszerében (gender system, gender studies) a nemek közötti munkamegosztást, a jogokat és kötelességeket konszenzuson alapuló elvárások szabályozzák. Hozzátette, hogy mindez a hatalmi, autonómiai, jóléti szférában egyenlőtlenségi viszonyokkal jár (Mason 1997: 150-175).

A megállapítások szinte mindegyikét kritika érte. Scott azt írta: „A gender a nemek közötti, észlelt különbségeken alapuló társas viszonyok alkotóeleme", egyben a „hatalmi viszonylatok elemi kifejeződése." (Scott 1986: 1067). Ugyanakkor hangsúlyozta, hogy a gender és a hatalom kapcsolatán kívül más módon is elképzelhető az emberek közötti dominanciaviszonyok kifejeződése (Scott 1986). Utóbbira utalt Risman is, aki nem kizárólag a gender irányt vélte a társadalom felosztására alkalmasnak, de struktúra-alkotó erőként jelentősnek tartotta (Risman 2004).

\footnotetext{
${ }^{2}$ Ld. bővebben: Braidotti, Irigaray, Schor, Weed munkáiban
} 


\section{KÖZELKÉP}

A teoretikus pártolók viszont ellenálltak. Elméletüket továbbfejlesztendő kijelentették, hogy a gender fogalmát nem a biológiai nem esszenciális adottságként kezelésére, hanem a biológiai nemnek mint konstrukció alapjára kellene építeni (Butler 1993). Butler ezen úton továbbmenve, az eszmekör egyik szélsőséges szószólójává vált, szerinte a „gender” kifejezés a test által, annak szocializációja és kulturalizációja folyamán felvett kulturális jelentést jelöli." (Butler 1993: 2). Később, Laplanche a gendert a szexus elé helyezte, amely szerinte bizonyos diszkurzív intervenciók révén közvetítődik. Példaként hozta, hogy az újszülöttnél a szexuálisan és genitálisan megkülönböztetett testképet megelőzi az ún. gender-hatás. (Laplanche 2007).

A radikális vonalhoz csatlakozók alapvető törekvése volt elfogadtatni azon elképzelést, hogy mivel szerintük az emberek társadalmi és/vagy nemi megnyilvánulásai biológiailag is sokfélék, ezért azok egyéni kontextusba helyezhetők. A gendert mindössze felelősnek, és nem okozónak tartották amiatt, hogy a biológiai nem ténye megkérdőjeleződik. Hivatkozásként az egyetértők megerősítésként, a tiltakozók kritikaként Butlert idézték ${ }^{3}$ Butler: „A biológiai nem egy elméleti konstrukció, ami idővel kényszerűen materializálódik. A biológiai nem nem egy egyszerű tény, vagy a test statikus állapota, hanem folyamat, amelynek során szabályozó normák materializálják a biológiai nemet." (Kuby: 2008: 63-64).

Idővel az ötletgazdák e megközelítéseket is felülírták, és a társadalmi nem fogalmát egy tág rendszerben intézményesült struktúrának tekintették, amely alkotó módon vesz részt önmaga meghatározásában és fenntartásában. ${ }^{4} \mathrm{~A}$ kifogásokkal együtt, a viták rámutattak arra, hogy a társadalmi nemi szerepek megfogalmazásában ilyen vagy olyan módon változtatásra mutatkozik igény. Jobb híján a gender eszmekör fokozatosan ismertté vált, s irányait tekintve további radikális elgondolások láttak napvilágot.

\section{A transzgender}

A fogalom sokféle értelmezéssel társult, köztük szubverzívnak ítélt elméletekkel (Gressgård 2010:13). Ilyen például a heteroszexualitást túlhaladott moralitásként kezelő, és vele szemben a változtatható nemi identitás elfogadásának, továbbá a biológiai nem és a megélt nem közötti szabad választás hirdetése. A transzgender terjedése jelentősnek mondható; alakuló szervezetek, kiadványok, folyóiratok és internetes portálok adnak hírt a szerteágazó, s egyre szaporodó irányzatokról. Eszerint léteznek a több-neműek, a több mint egy nemi identitással rendelkezők (férfi, nő vagy egyéb), amely változtatható két- (bigender), három- (trigender), vagy több nemű (polygender) identitásra. További kategória a nem-nélküliek csoportja, akik

\footnotetext{
${ }^{3}$ Ld. még: Sandy Stone gender-mainstreaming írásaiban.

${ }^{4}$ Ismertebb elméletgazdák: Derrida, Foucault, Lacan, Butler, ill. ld. lentebb.
} 


\section{KÖZELKÉP}

nem rendelkeznek konkrét nemi hovatartozással, vagy nem érzik magukat semmilyen neműnek (pl. nemtelen (agender), nem-semleges (genderneutral). Önálló csoport még a változó genderrel rendelkezők, akik különböző időszakokban különböző nemi identitásúak vallják magukat (változó nem (gender fluid). A harmadik nem kategóriáját (thirdgender) a férfi és a női identitástól különböző, harmadik nemi csoport alkotja, vagyis a nemek közötti, két bináris identitást (férfi és nő) gyakorlók. ${ }^{5}$

Az elképzelések óriási vihart kavartak a mérsékeltebb gondolkodásúak körében. A konzervatív Kuby, a született nemiség relativizálásáról beszélt, és felháborodva idézett a Hamburgi Egyetem tanulmánysorozatából, amely felvázolta a modern gender- perspektívákat: „A gender-aktívisták célja 'a nemek egyértelműségének megszüntetése' [sic!] és 'egy képlékeny identitás kialakítása'. A transzgenderek a 'kétneműség merev normáját támadják'. Azt akarják, hogy jogilag ne a biológiai, hanem az önkényesen választott nem legyen érvényben, és ezt jegyezzék be a hivatalos iratokba.” (Kuby 2008: 65-66). Kuby és követői ${ }^{6}$ tiltakozásának fő oka volt, hogy attól tartottak, a transzneműek hivatalos elismerésével „a heteroszexualitástól való minden szexuális eltérés normálisnak és megengedettnek nyilvánítható." (Kuby 2008 :65).

A posztfeminista pártolók viszont a gender ezen irányzatát tökéletes elméletnek tartották, mivel az egyazon emberben létrejött férfias és nőies személyiségjegyek elegye szerintük előnyt ígér, és kiterjedt személyes szabadságot biztosít az önmegvalósításhoz. Konzervatív körökben viszont ezúttal is a nemiség relativizálásáról beszéltek (Kuby 2008). Továbbá veszélyesnek tartották, hogy az óvodában és az iskolában elhagyják a tradicionális szerepek begyakorlását (pl. anya a konyhában főz, apa autót szerel az udvaron), és az újfajta nevelésben a tudatosan kreált újgeneráció kinevelését látták. ${ }^{7}$ Intő jelnek vették az Európai Parlament döntését, miszerint a tankönyvekből, számítógépes játékokból, marketingből, plakátokról száműzni kell a szokásos férfi és női magatartásformák megjelenítését. ${ }^{8}$ Mások a transzgendert és kapcsolódó kategóriáját a teljes gender-irányzattal azonosították, s annak tudatos konstruáltságáról, politikatartalommal telítődéséről beszéltek:

${ }^{5}$ A nemi identitás-meghatározások száma folyamatosan nő (napjainkban 50-70 közé tehető a publikált kategóriák száma). Takács Boglárka, 2013. július 2.: https://www.nyest.hu/hirek/on-binaris-nemu; Transvanilla, 2018. január 7.: http://transvanilla.hu/genderqueer/genderqueer-identitasok; Tomka Ferenc, 2017 copyright: http://tomkaferenc.hu/alapkerdesek/hazassag-szerelem-szexualitas-tudomanyos-szemmel/a-szexualis-forradalomtol-a-gender-forradalomig/ - A letöltések ideje: 2017. szeptember 20.

${ }^{6} \mathrm{Pl}$. Lee Mundy, Dominik Klenk, Konstantin Mascher, Tomka Ferenc stb.

${ }^{7} \mathrm{Pl}$. az USA elnöke rendeletben előírta, hogy az állami iskoláknak és közintézményeknek kötelezően lehetővé kell tenniük, hogy a nemüket megváltoztató amerikaiak ne a születésükkor bejegyzett nemük szerinti mosdót használhassák, hanem a választott nemük szerintit. Eddig tizenegy állam tiltakozott ellene (2016. május).

${ }^{8}$ Az Európai Parlament Állásfoglalására Irányuló Indítvány. A6-0199/2008 


\section{KÖZELKÉP}

„Hallott már a szomatikus fundamentalistákról? Ezt a címkét ragasztják mindenkire, aki abból indul ki, hogy az emberiséget nők és férfiak alkotják, hogy csak nők és férfiak léteznek, nem pedig nemek sokasága. A szomatikus (szóma, görög szó, jelentése: test) fundamentalista, aki egyúttal keresztény is, azt hiszi, hogy Isten az embert nőnek és férfinak teremtette, és még nem fogta fel, hogy minden "gender". Az angol nyelvü 'gender' kifejezés a szociális nemet jelenti, ellentétben a „sex" kifejezéssel, amin a biológiai nemet értjük. A gender tehát tágabb értelemben az érzett nemi identitást kifejező nemi szerep. A genderrel pedig éppenséggel jogok járnak, a gendert figyelembe kell venni a törvényekben, a szabályozásokban és a kulturális értékek alakításában. Ami pár évtizeddel ezelőtt csupán néhány tudós elméletében fogalmazódott meg, az időközben politikai programmá vált." (Mascher, In: Klenk, $2009: 3)$

A transzgender hívei - noha közülük többen tiltakoznak az ellen, hogy identitásuk nem szexuális alapú -, a legtöbb alkalommal testileg is kinyilvánítják 'gender-váltásukat' (öltözködés, operáció, mentalitás, attitűd stb.). Ilyen esetekben valójában nem a mentalitás keveredéséről, hanem a tradicionálisan férfias és nőies szerepkörök, viselkedési sztereotípiák ideológiai átvételéről van szó, amely nem értékelhető a biológiai nem megváltoztatásaként. A gender irányzat ugyanakkor rámutatott arra, hogy a XX-XXI. századi ember életmódja, viselkedése és mentalitása jelentősen változott. Az emberek többsége kevéssé hordoz magában tisztán feminin, és tisztán maszkulin jegyeket. A jelenség definiálására számos kísérlet történt, s a mintakövetésről több spirituális okfejtés is napvilágot látott. Visszatekintve, e próbálkozások a maguk módján katalizátorként szolgálhattak a gender-eszmekör tárgyalt irányzatai kialakításához.

\section{A hímnős, az androgün}

Az újfajta férfi- és női szerepkeveredést némely elgondolás az androgínia címszó alatt tárgyalta, amely rendszeresen felbukkan a tudományban, és a közgondolkodásban. ${ }^{9} \mathrm{Az}$ androgün- allegória valójában a biológiai hímnősségre épül, mitológiai és ókori történetei lírai példákat hoznak az egész kettéhasadásáról, és az egymás-keresésről. Erre építve Alfermann egyik írásában hosszan taglalta, hogy az egalitárius társadalmakban a nemi szerepek nem lehetnek kizárólagosak, és az ember mentális androgünként, igénye szerint váltogathatja szociálpszichológiai szerepeit, miközben biológiai neme állandó marad (Alferman 1992).

Szerinte e komplementer kombinációban integrálódnak a férfias és a nőies vonások, amely újszerű viselkedésformát eredményez. Ugyanő feltételezte, hogy az

\footnotetext{
${ }^{9}$ Bővebben ld.: Platón, 189a-193d; és pl. C. G. Jung: Analitikus pszichológia.
} 


\section{KÖZELKÉP}

újonnan kialakult attitűd mentes lesz a korábban, egyik vagy másik fél számára kötelezően előírt viselkedési előítéletektől. Összességében az androgünben összeadódó személyiségjegyek szocializációs előnyökkel járhatnak, mivel az egyén már nem csak férfi, vagy csak női szemmel látja a világot (Alfermann K. F. Wessel - H. A. G. 1992).10

\section{Dialektikus szexualitás}

Fenti elmélethez mások is csatlakoztak. Hell, a férfivélemények közül Kolbenschlagot idézte, aki pl. úgy vélte, hogy a hímnős-koncepció segítheti a női öntudat kialakítását. Az afelé vezető út első lépéseként a női jelenlét és alkotás szükségességét határozta meg (Hell, 2006): „Ha a nő nem dolgozik, nincs lehetősége arra, hogy felülemelkedjen a hétköznapok világán, és autonóm lénnyé váljon." (Hell, 2006:105). Hangsúlyozta, hogy az aktivitás nem a férfiak melletti kiszolgáló- aktivitást jelenti mint pl. titkárnő, beosztott, vagy feleség -, hanem az egyénnek teljes önállóságot kell elérnie a magánéleti kapcsolatokban is: „Ahogy a nő öntudatára ébred egzisztenciális álmából és alárendeltségéből, a nagy ő széttöredezik szeretőkké, barátokká és férjekké. A szeretett férfi sokoldalú kell, hogy legyen, képesnek kell lennie arra, hogy el tudja játszani mindazokat a szerepeket." (Hell 2006: 105-106). Kolbenschlag határozottan elutasította a homoszexualitással vont párhuzamot, s azt a feltételezést, hogy az aktivitással nők a férfiasabbakká válnak: „sokkal inkább azt jelenti, hogy a dialektikus szexualitás, az alkotó én érdekében feladjuk a sztereotip nemi szerepeket." (Hell, 2006: 81-89).

Todorov az erények kapcsán fejtegette, hogy bizonyos szempontból mindenki hiányos és rendellenes, de az emberibb emberré válás modelljét ő is az androgünben látta. Szerinte a férfit a benne rejlő nőiesség menti meg a rossztól. Példaként viszolyogva említette a férfiak egymás közötti alpári viselkedését és erőszakosságát, amelyeket a nőies jegyek szelídíthetnek, miáltal akár kiküszöbölhetők a hibás személyiségjegyek. Mintegy elmarasztalásként azonban fölvetette a kérdést, hogy vajon a nőknek egyáltalában szükségük van-e a férfiasságra (Todorov 1991).

\section{Feminista konstitúció}

Feminista körökben radikális elgondolások is születtek a témában. Trebilcot például kidolgozta a monoandrogínia és a polyandrogínia foglamát (Trebilcot 1982). Előbbi szerint minden embernek fejlesztenie kell magában a tradicionális férfi és női szere-

${ }^{10}$ Alfermann egy skála segítségével tipizálta a férfias és a nőies tulajdonságokat, s megalkotta a maszkulin, a feminin, az androgün és a határozatlan (vagy bizonytalan) személyiségtípust. Mindebből a feminin férfiak és maszkulin nők és variánsainak kategóriáját állapította meg. Alfermann/ K. F. Wessel H. A. G. 


\section{KÖZELKÉP}

pekhez kapcsolódó pozitív tulajdonságokat, amelyek keveredésével újonnan kialakult személyiségtípus jöhet létre, és akkor az emberek hasonló tulajdonságokkal bírnának. E nézet követendő személyiségprofilt írt elő, és előirányozta, hogy az emberek konstruált, egyedüli ideálnak feleljenek meg; tehát férfiasak, és egyben nőiesek is legyenek. Az ekképpen létrejövő ideális típusról, az elméletgazda szerint minden egészséges embernek példát kellene vennie.

A polyandrogínia, szabadságtartalmánál fogva a társadalmi nem megválasztásában jóval megengedőbb volt a monoandrogíniánál. Az elmélet hívei szerint az embernek lehetősége van arra, hogy született nemétől függetlenül bármelyik biológiai nemhez kötött, erkölcsileg és pszichológiailag elfogadható, de a saját egyéniségéhez közelálló tulajdonságokat átvegye, és társadalmi nemi szerepeit is azok alapján válassza. ${ }^{11}$ Eszerint, ha egy nő úgy érzi, hogy a férfias sztereotípiáknak jobban eleget tud tenni, válassza azokat, miközben visszautasítja, hogy a viselkedésbeli irányultságot a biológiai nem határozza meg. Összességében a mono- és a polyandrogínia elmélete elhatárolódott mindenfajta kötelezőségtől, amikor hangsúlyozta, hogy nem feltétlenül követendő ideálokról van szó, sokkal inkább a választás szabadságáról.

\section{A doing gender}

Judith Lorber írása, a 'Night to His Day': The Social Construction of Gender a maga korában (1994) című esszé valódi bestsellerré vált, amelyben a szerző arról szólt, hogy a mindennapi életben miként konstituálódnak a társadalmi nemi szerepek (Lorber 1994). A kifejtésben az interakcionista doing gender-elképzelésre hivatkozott, miszerint a társadalmi nemek a hétköznapi interakciók révén újrakonstruálódnak. Lorber szerint a konstrukciók által olyan elkülöníthető státusok jönnek létre, amelyek társadalmi intézményként is felfoghatók.

A státusokban viszont - állította Lorber - társadalmi rétegződés figyelhető meg: férfiak és nők hierarchikus viszonyban állnak egymással; a férfiak tevékenysége magasabb rendű és értékesebb, mint a nőké. A társadalmi nemi egyenlőtlenség tehát továbbra is azt jelenti, hogy nők és férfiak társadalmi státusa nem azonos. Lorber a nőiség és a férfiság fogalmát önmagában üresnek tartotta, vagyis csatlakozva a szabadon választható nemi tartalmak elvéhez, azt társadalmi konstrukció és tanulás révén gondolta kitölteni. Hasonló véleményt fogalmazott meg Rudman és Glick: szerintük a férfiak és nők között megfigyelt viselkedésbeli eltéréseket a nemekre vonatkozó kulturális hiedelmek hozzák létre (Rudman - Glick 2008).

\footnotetext{
${ }^{11}$ Pl. uo. ill. Joyce Trebilcot, CarolyneBird, Jessie Bernard, Carolyn Heilborn stb.
} 


\section{KÖZELKÉP}

\section{Dinamizmus- és queer- és egyéb elméletek}

Fentiek kiegészítendők a dinamizmus- és a queer-elmélettel. A dinamikus vagy konstruktivista gender-felfogás a dichotómiák felszámolását helyezte célkeresztbe. Követői szerint az ellentétpárok alkalmazása újratermeli a biológiai kiindulópontú társadalmi nemi kategóriákat. Ezen apriori, bipoláris meghatározásokkal szemben - pl. aktív-passzív; fölérendelt-alárendelt; női másság-férfi azonosság; értékes-értéktelen dichotómiák - a dinamizmus-elmélet fluid-természetű (változó) gender-identitásokat proponál. A magyarázat szerint erre azért van szükség, hogy az egyén változatos szerepkörökben, változatos kontextusokban, különféle performanciákat alkalmazhasson. ${ }^{12}$

A queer-elmélet alapgondolata, hogy a társadalom tagjai, a nemi identitás és irányultság szemszögéből nézve, mindössze a bináris oppozíciók elavult rendszere révén képződött hetero- vagy homoszexuális emberek csoportja. Az indok ismerős: a társadalmi nem, a szexus és a szexualitás fogalmai csupán társadalmi konstrukciók, amelyek tradicionális alapjának helyébe, az egyén önmaga által választott szexuális orientációját kell léptetni (LMBTQ (+IA) = leszbikus, meleg, homoszexuális, biszexuális, transznemű, hermafrodita + queer, + I = interszexuális ,+ A = aszexuális). ${ }^{13}$

Az elméletsor helyes irányát és szükségességét azzal indokolták, hogy szabad utat biztosít az egyén részére abban, hogy szexualitását, identitását egyfajta szocializációs korrekcióval bármikor módosíthassa. A queer-szemlélet követőinek a homo-irányultságok (leszbikus, homoszexuális stb.) kifejtésével és azok egyenlő mértékre emelésével, nem titkolt célja volt a gender addigi határainak áthágása. Butler és társai tkp. dekonstruálták a biológiai nem fogalmát, amely szerint a született nemiséghez kapcsolt cselekvés nem egy adottságnak megfelelő viselkedésformák, hanem szabadon választható kulturális szubjektumok kifejezése (Butler 2005).

\section{Gender-kritika}

A gender „újrafogalmazott” ideológiája először az ENSZ 1995-ös pekingi női világkonferenciáján került nyilvánosság elé. A záródokumentumban hivatalosan bevezették a gender mainstreaming kifejezést, amely „mint a nők, a melegek, biszexuálisok, transzszexuálisok elismeréséért, egyenrangúságáért, és a kérdés hirdetéséért folytatott „fó-áramlat” jelent meg (Dale O’Leary 1997). Holott - amint az a fentiekben

${ }^{12}$ Queer-elmélettel foglalkozó publikációk, pl.: Judith Butler: GenderTrouble: Feminism and the Subversion of Identity, London New York, Routledge, 1990. Steven Seideman: Deconstructingqueertheoryor the under-theorization of the social and the ethical. In: Social Postmodernism. Cambridge, 1995. Lisa Duggan: A különbözőség közössége. Replika 1998/XII.

13 Referencia-lista: https://www.e-ir.info/2014/10/31/lgbt-politics-queer-theory-and-international-relations/ Letöltés ideje: 2017. december 5. 


\section{KÖZELKÉP}

már elhangzott -, a gender fogalmát eredetileg a nemek társadalmi egyenlőségének érvényesítésére alkották meg azzal a céllal, hogy férfiak és nők azonos mértékben részesüljenek a társadalmi javakból. Az ellenzők - pl. Dominik Klenk- ezúttal is szót emelt: „Ha közelebbről megnézzük, egy olyan koncepció körvonalazódik, amelynek csak az előtérben célja a nemek egyenlősége; a háttérben a nemnek mint kategóriának, a férfi és a nő közötti különbségnek a felszámolásáról van szó. Ezt szolgálja a 'gender' fogalmának politikai eszközként való bevezetése. Az adott 'férfi és nő', 'férfias és nőies' meghatározások sikeres kiküszöbölése felé tett első lépés - így magyarázzák nekünk a gendermainstreaming teoretikusai - a 'nem' egyértelmű fogalmának elhomályosítása és a nemi kategóriák összezavarása." (Klenk, 2009: 4)

Mindezt kiegészítve megemlítendő, hogy a korai, és modern gender-struktúra is, általában véve inkább férfi-centrikus, mint egyenlőségre törekvő, amelyet többen szóvá tettek. Scott a munka- egyenlőség- egyetemesség kategóriákat vizsgálta, amelyből azt szűrte le, hogy a nyilvános terek általában - és benne kiemelten a munka világa -, legtöbbször a férfiasság szférájaként jelenik meg. A fó probléma szerinte nemcsak az, hogy a férfiasnak tartott tevékenységek továbbra is felülértékelődnek a nőiesekkel szemben, hanem hogy a nemek teljesítménye a korábbi, sztereotip megítélésekhez kötődik: „[...] kitermelik azokat az implicit sémákat is, melyekkel az értékes és értéktelen munkát jellemezzük, melyek szerint a politikai életben való részvételnek más-más értéket tulajdonítunk, és mely következtében az egyetemességre való hivatkozások valójában a maszkulinitást előfeltételezik, irányában elfogultak." (Scott 1994: 287)

Lorber tematikus értelmezésében a gender olyan társadalmi intézmény, amely társadalmi státusokat hoz létre, és azok nem egyenlők. Szerinte a társadalom tagjai ugyanazokat a tevékenységeket, amennyiben férfi végzi, értékesebbnek tartja, minek következtében az azonos etnikai csoportba vagy osztályba tartozó férfiak automatikusan a nők fölé kerülhetnek (Lorber 1994). A konstruált gender eszmekörben a nemi kategóriák így szilárdak maradnak, és folyamatosan újratermelik az androcentrikus megkülönböztetéseket, miközben a feminizmus egyik legfontosabbnak mondható célkitúzése, a bináris oppozíciók (férfi: értékes - nő: értéktelen) kiegyenlítése, és törlése elmarad. A gender-eszme problémáinak megoldására tehát az ellenzők visszatértek volna az eredeti megfogalmazáshoz, és az ésszerű konszenzust keresték, vagyis azt, hogy férfi és nő, biológiai nemét megtartva, a feladatokat egyenlő jogokkal és kölcsönös megállapodás szerint végezhesse.

A megállapodást a komplementerség jegyében is lehet értelmezni, miszerint két megváltozott társadalmi nemủ ember is remekül kiegészítheti egymást, ami jó érv, és logikusnak is tűnik, de a gender-hívők és a nem-hívők részére ez kissé elégtelen magyarázat lenne. A gender-elmélet korai és radikális irányzatai arra a kérdésre, hogy társadalmi értelemben mi a nő, és mi a férfi, azt válaszolják, hogy a társadalmi neme mindenkinek az, amelyiket választja magának. Női-szempontú és kultúrkriti- 


\section{KÖZELKÉP}

kai értelemben viszont a nő továbbra is az, amivé identitását a férfi alakította/alakítja, s azokat a sztereotip szerepmintákat, erkölcsi erényeket és normákat szükséges követnie, amelyek által a férfi látni, és láttatni kívánja őt. A szélsőséges gender-eszmekör viszont mindezeket inkább erősíti, mintsem az egalitárius megítélés irányába tolná.

\section{Megoldások válaszra}

A nők szempontjából a gender elmélet mérsékeltebb és radikális irányzatai sem értékelhetők pozitívan, mert a szabadon megválasztható nemi szerepek hirdetői részére nem az a kérdés, hogy a társadalmi nemi szerep milyen legyen, hanem az, hogy férfias legyen vagy nőies legyen-e. A gender-kritikusak egyik szószólója írta: „[A gender- hívek] a férfi és a nő nemi különbözőségét társadalmi konstrukciónak tartják, melyet a 'heteroszexuális patriarchátus' talált ki. Szerintük így nemcsak egy kisebbséget helyeznek elnyomás alá és diszkriminálnak, hanem általánosságban jogtalanul korlátozzák az ember szabadságát. 'Kényszer- heteroszexualitás' áll fenn, amit meg kell haladni, amennyiben az ember maga határozhatja meg - 'biológiai nemétől' függetlenül - saját társadalmi nemét." (Kuby 2008: 63) Másfelől, a modern irányokat tekintve a gender azért nem lehet előrevivő, mert a született nemi orientációjukat negligáló egyének (pl. transz-irányultságú férfiak) a gender által bekerülnek a nők csoportjába, miáltal a nőket újból egy különösen kezelt, szubszexualitású csoport részeként tartják számon, mely bármely ekvivalencia igyekezete ellenére sem lehet egyenértékű a férfiak csoportjával.

A társadalmi nemi szerepek változásának más oldalról megközelítése viszont magyarázatot adhat a társadalom szélesebb körei részére. Az anya-háziasszony-partner-dolgozó prioritás a kétezredik év első felére tartósan megfordulni látszik. Korábban a nemi szerepek között a férfias és a nőies sztereotípiák elkülönítve futottak, az anya és az apa feladatköre és státusa elvált egymástól. A létfenntartás gyakorlati fogalma átalakult, a közéleti megnyilvánulások képzettséget, gyakorlatot kívánnak meg, és döntési helyzeteket generálnak. Az új feladatoknak a nők (és sok esetben a férfiak is), csak életstílusuk, gondolkodásuk megváltoztatásával tudtak megfelelni. A mentalitásváltozás hatására a tradicionális női szerepek háttérbe szorultak, és a sztereotip férfiszerepek követése az érvényesülés érdekében szükségessé vált. ${ }^{14}$

A tényleges társadalmi nemi szerepek megválasztása - a biológiai nem megtartása mellett - új mentalitásformákat hoztak létre, amelyek önmagukban lehetnek férfi-

${ }^{14}$ Ld. kortárs, ill. a kor női szerepeit vizsgáló magyarországi kutatók eredményei: Acsády Judit, Gyáni Gábor, Hell Judit, Horváth Júlia Borbála, Hrubos Ildikó, Huszár Ágnes, Kapitány Ágnes-Kapitány Gábor, Kéri Katalin, Kiss Róbert, Koncz Katalin, Kopp Mária, Nagy Beáta, Neményi Mária, Pongrácz Tiborné, Schadt Mária, Tóth Olga (stb.). 


\section{KÖZELKÉP}

asak és/vagy nőiesek is. Az egyénben a feladatok elvégzése érdekében keverednek a sztereotip viselkedés- és gondolkodásformák, miáltal körülírható a köztes- vagy intermentalitás fogalma (Horváth 2008; 2015). Az intermentalitás értelmezhető egyfajta emancipációs folyamat részeként, ill. törvényszerűen bekövetkező jellegzetességként abban az értelemben, hogy a fennmaradáshoz és az érvényesüléshez szükséges gondolkodás és tulajdonságok átvételét kívánja meg nőktől - és férfiaktól.

\section{Összegzés}

Ahogyan a fentiekben történt kiemelés: a gender eredetileg nem a férfiak és nők biológiai, hanem viselkedés- és mentalitásbeli változtatására törekedett. Az elképzelés korai, és későbbi irányultsága közötti különbség az, hogy utóbbi az ember, és kiterjesztve az emberiség egy olyan alapvető alkotóelemét relativizálja, amely nélkül könnyen nem-létezővé válhat. Vagyis férfi és nő létezése és biológiai különbözősége napjainkban is alapeleme a folytonosságnak. A szabadon megválasztható társadalmi nem esetében, az idézett véleményekben azt tartják lényeges kérdésnek, hogy egy nő, akarata szerint élhet-e férfiéletet, vagy egy férfi női életet, amely a tradicionális formák és elvárások közepette tiszta formában szinte lehetetlen.

Mindezeket egybevetve tény, hogy a társadalmi nemi szerepkövetés konvencionális határainak átlépése folyamatban van. Iránya, mértéke és a felkínált lehetőségek az útkeresés jegyeit és szükségességét mutatják. A gender hívők és ellenzők a társadalmi nemi szerepek kapcsán érveket és ellenérveket sorakoztattak fel. Kiemelt kérdés volt, hogy a nemi szerepváltozás a biológiai nem negligálásával, vagyis a nemiség relativizálásával jöjjön-e létre.

A gyakorlatban a társadalmi nemi szerepek váltogatása azonban más kategóriát képez, hiszen valóban nem létezik olyan férfi és nő sem, aki tiszta formában csak férfias, ill. csak nőies tulajdonságokkal rendelkezne. A társadalmi nemi szerepek diverzitása a hétköznapokban sokkal inkább változás, mintsem mesterséges változtatás eredményeként értékelhető, amely a szükséges mentalitásváltozás mellett jöhet létre. A másik jelentős kérdéskör volt, hogy a transz-neműség elenyésző számú érintettje miatt jogos-e, és érdemes-e egy faj biológiai felforgatása.

\section{Irodalom}

Alfermann, D. (1992): Maskulinität/Femininität versus Androgynie. In: K.F. Wessel H. A. G. Bosinski: Interdisziplinäre Aspekte der Geschlechterverhältnisse in einersich wandelnden Taschenbuch Zeit. Bielefeld

Butler, J. (1993): Introduction. In: Butler, Judith: Bodies That Matter. On the Discursive Limits of „Sex”. Roudedge. New York. 2-63 
www. metszetek.unideb.hu

\section{KÖZELKÉP}

Butler, J. (2005): Jelentős testek. A „szexus” diszkurzív korlátairól. Új Mandátum Könyvkiadó. Budapest

Európai Parlament (2008): Az Európai Parlament Állásfoglalására Irányuló Indítvány. Online: http://www.europarl.europa.eu/sides/getDoc.do?pubRef=-//EP //TEXT+MOTION+B6-2008-0051+0+DOC+XML+V0//HU letöltve: 2008. január 23.

Gressgård, R. (2010): When transtranslates intotolerance - or wait monstrous? Transsexual and transgender identity in liberal humanist discourse. Sexualities. Online version: DOI: 10.1177/1363460710375569 2010 13:512-550 letöltve: 2018. január 10.

Hell Judit (2006): Van-e feminista filozófia? Áron Kiadó, Budapest

Horváth Júlia Borbála (2008): Újnőkorszak. L’Harmattan, Budapest

Horváth Júlia Borbála (2015): Lánylegény. L'Harmattan, Budapest

Huszár Ágnes (2009): Női nyelv? Férfi nyelv? Gender nyelvészet Magyarországon. Magyar Tudomány, Budapest

Klenk Dominik (2009): A nemek összezavarása. Gender mainstreaming. A férfi és a nő vége? Kairosz Kiadó, Budapest

Kuby, G. (2008): A nemek forradalma. Kairosz Kiadó, Budapest

Lacan, J. (1977): „The Four Fundamental Concepts of Psychoanalysis, 1964.” In: Alan, S. (ed.) The Seminar, vol. 11. Hogarth Press and Institute of Psychoanalysis, London

Laplanche, J. - Fairfield, S. (2007): „Gender, Sex and the Sexual.” In: Studies in Gender and Sexuality. 2007. Online DOI: 10.1080/15240650701225567. 201-219

Lorber, J. (1994): 'Night to His Day': The Social Construction of Gender. Yale University Press. In: Phillip Hamilton McMillan of the Class of 1894, Yale College, New Haven, 1-11

Mason, K. O. (1995): Gender and Demographic Change: What Do We Know? International Union for the Scientific Study of Population [IUSSP], Liege

O'Leary, D. (1997): The gender agenda. Redefining equality. Christl Vonholdt. Vital Issues Press Lafayette, Los Angeles

Platón (2001): Az állam. Lazi Kiadó. MEK/http://mek.niif.hu/03600/03629/03629. htm 2018. március 8.

Risman, J. B. (2004): Gender as a Social Structure: Theory Wrestling with Activism. Gender \& Society. North California State University press, Volume 18, issue 4: 429-450. North California, 429-450

Rudman, L. A. - Glick, P. (2008): The Social Psychology of Gender. How Power and Intimacy Shape Relations. Guilford Press, New York 
www. metszetek.unideb.hu

\section{KÖZELKÉP}

Scott, J. W. (1986): Gender: A Useful Category of Historical Analysis. The American Historical Review, New York City, 1053-1075

Todorov, T. (1991): Face à l'extrème. Seuil, Paris

Tomka Ferenc (2017): A szexuális forradalomtól a gender-forradalomig. http://tomkaferenc.hu/alapkerdesek/hazassag-szerelem-szexualitas-tudomanyos-szemmel/a-szexualis-forradalomtol-a-gender-forradalomig/ 2017. november 23.

Trebilcot, J. [1982] (2012): Two form of antagonism. In: Thomas A. M. - Jane S. Z. David de Grazia: Social ethics: Morality and Social Policy. Thomas Mappes Paperback, New York. 689-695 